\title{
Association of polymorphisms in avian apoVLDL-II gene with body weight and abdominal fat weight
}

\author{
Hassan Hussein Musa, ${ }^{1,2}$ and Guo Hong Chen ${ }^{1 *}$ \\ ${ }^{1}$ College of Animal Science and Technology, Yangzhou University, Yangzhou, 225009, China. \\ ${ }^{2}$ Department of Animal Production, Faculty of Veterinary Science, University of Nyala, Sudan.
}

Accepted 23 January, 2007

\begin{abstract}
To investigate the association of avian apoVLDL-II gene polymorphism with body weight and fat, exactly 120 genetically fat (Anka) and lean (Rugao) chicken reared under the same environment and management were selected. Blood samples from the respective populations were taken for DNA extraction, and then slaughter for fat determination. Polymorphism was detected by PCR-RFLP and PCR-SSCP techniques. Gene frequency was non significantly different between population at VLDL6 and VLDL10 loci. However, in VLDL9 and VLDL17 loci the gene frequency was differed significantly $(P<0.01)$ between populations. Polymorphism in apoVLDL-II gene was significantly $(P<0.05)$ associated with body weight and fat weight at VLDL9 and VLDL17 loci in lean chicken. In addition, polymorphism of apoVLDL-II gene at VLDL6, VLDL9 and VLDL10 loci was significantly $(P<0.05)$ associated with body weight and fat weight.
\end{abstract}

Key words: Polymorphism, apoVLDL-II, body weight, fat, avian.

\section{INTRODUCTION}

In various cells, including adipocytes, lipoprotein lipase (LPL) enhances cellular binding and uptake of lipoproteins (Schneider et al., 1990). Like chylomicrons, very low density lipoprotein (VLDL) undergoes constant changes in the plasma. At onset of egg-laying in the chicken, plasma levels of apolipoprotein VLDL-II (apoll) increase dramatically (Nimpf et al., 1988; Schneider et al., 1990).

The de novo fatty acid synthesis in birds takes place mainly in the liver, adipose tissue growth and subsequent fattening associated with the availability of plasma triglycerides, which are transported as components of lipoproteins. VLDL genes specify the most abundant mRNA species present in livers of hens or estrogentreated roosters (Hache et al., 1983). In growing birds, VLDL is the major transporter of triglycerides, and attempts to reduce excessive fatness in poultry have involved the control of VLDL metabolism.

\footnotetext{
${ }^{\star}$ Corresponding author. E-mail: ghchen@yzu.edu.cn, hassan_hm30@yahoo.com.
}

Therefore, lean and fat chicken lines have been divergently selected for adipose tissue weight (Leclercq et al., 1980) and for VLDL plasma concentration (Whitehead and Griffin, 1984). Studies performed in lean and fat line by (Leclercq et al., 1980) indicated that the difference in adiposity between lines was not the result of a difference in food consumption or in metabolic utilizetion of energy. Stearoyl-CoA desaturase activity and plasma VLDL concentration were found to be higher in the fat line, suggesting a higher lipogenesis rate in this line (Legrand and Hermier, 1992).

The low density lipoprotein (LDL) and very low density lipoprotein (VLDL) particles in meat type cockerel chickens occur in much smaller proportion compared to high density lipoprotein (HDL), with LDL exceeding that of VLDL (Peebles et al., 2004). In the mature egg-laying hens, VLDL particles are the most predominant lipoprotein (Walzem et al., 1994). In Obese functionally castrated hens, where plasma level of apo-VLDL-II was low, plasma LPL activity was elevated, because obese functionally castrated hen had lower ovarian weight and plasma apoVLDL-II and higher post heparin plasma LPL activity than obese laying hen (Jaccoby et al., 1996).

The objective of this experiment was to detect polymer- 
Table 1. Primers sequences, location, PCR product and annealing temperature of chicken ApoVLDL-II gene.

\begin{tabular}{|l|l|l|l|c|c|}
\hline Primers & Sequences (5'-3' flanking region) & Direction & Location & PCR product & Annealing temperature \\
\hline VLDL6 & CCTCTATGACATGGT TGCCT & Sense & $1549-2041$ & $492 \mathrm{bp}$ & $58^{\circ} \mathrm{C}$ \\
VLDL6 & ATGGGTTTGACCCTGCTATG & Antisense & & & \\
VLDL9 & CACCTTTCTAAATGCACAGT & Sense & $2490-2759$ & $289 \mathrm{bp}$ & $53.4^{\circ} \mathrm{C}$ \\
VLDL9 & GCAATGATCTTCTGAATGAC & Antisense & & & \\
VLDL10 & ATTGACTAGCGTGAGATTCC & Sense & $2788-3071$ & $303 \mathrm{bp}$ & $57^{\circ} \mathrm{C}$ \\
VLDL10 & ATGATGGTGCAGTTCTTCTT & Antisense & & & \\
VLDL17 & ACTGCCTATTCCTGCCTTCT & Sense & $4199-4479$ & $280 \mathrm{bp}$ & $56^{\circ} \mathrm{C}$ \\
VLDL17 & CACCGACTTTTCTTCCAACT & Antisense & & & \\
\hline
\end{tabular}

phisms in apoVLDL-II gene and study its association with body weight and fat in chicken.

\section{MATERIALS AND METHODS}

\section{Experimental stocks}

The genetically fat (Anka) and lean (Rugao) chicken were reared under the same environment and management. $0.5 \mathrm{ml}$ blood samples were taken from the wing vein of respective populations for DNA extraction. Chickens were slaughtered, carcasses were eviscerated and dissected manually, and abdominal fat weight was estimated. The percentage of abdominal fat weight was expressed as a ratio of body weight (Musa et al., 2006).

\section{DNA Isolation and primers design}

Genomic DNA was isolated from the whole blood using saturated salt method (Sambrook et al., 1989). Primers were designed based on the published sequences in Gene bank, accession number (J00810). One pair of ApoVLDL-II primer for PCR-RFLP was chosen based on the primer design by (Li et al., 2005). PCR-SSCP primers were design using Primers Primers 5.0, Oligo 6.0 and DNA star softwares, their related information was presented in (Table 1).

\section{PCR-RFLP}

PCR-RFLP amplification of VLDL6 primer was carried out in total volume of $25 \mu \mathrm{l}$ containing $100 \mathrm{ng}$ of template DNA, $5 \mathrm{pmol}$ of each primer, 10X PCR Buffer (Mg2plus), $2.5 \mathrm{mM}$ dNTP mixture and (5 $\mathrm{U} / \mu \mathrm{l}$ ) of Taq DNA polymerase (TakaRa Biotechnology Dalian Co., Ltd). The amplification cycle entailed $3 \mathrm{~min}$ of denaturation at $94^{\circ} \mathrm{C}$, followed by 35 cycles of $1 \mathrm{~min}$ at $94^{\circ} \mathrm{C}, 1 \mathrm{~min}$ at $58^{\circ} \mathrm{C}$ and $1 \mathrm{~min}$ at $72^{\circ} \mathrm{C}$. This was followed by 10 min of extension at $72^{\circ} \mathrm{C}$. PCR products were checked in $0.8 \%$ agarose gels stained with ethidium bromide to determine the presence of product. Thereby, $10 \mathrm{ul}$ of each PCR products were digested overnight at $60^{\circ} \mathrm{C}$ by $3 \mathrm{U}$ of $\mathrm{SfCl}$ restriction enzyme (Sangon, China). The digested fragments were electrophorsed using $10 \%$ polyacrilamide gels in 1XTBE buffer at a constant voltage of $120 \mathrm{~V}$ for $4 \mathrm{~h}$. DNA was visualized by staining the gel with silver and their photo were taken by Olympus digital camera.

\section{PCR-SSCP}

Single strand conformation polymorphism analysis was performed as described by (Orita et al., 1989). The analysis was carried out in $20 \mu \mathrm{l}$ of PCR product for all primers. The total volume used included
$100 \mathrm{ng}$ of template DNA, $5 \mathrm{pmol}$ of each primer, 10X PCR Buffer

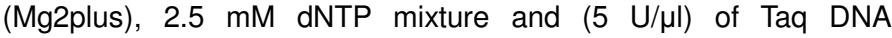
polymerase (TakaRa Biotechnology Dalian Co., Ltd.). PCR condition was carried out by thermal cycle. Initial denaturation for 3 min at $94^{\circ} \mathrm{C}$, was followed by 30 cycles of denaturation at $94^{\circ} \mathrm{C}$ for $30 \mathrm{~s}$, annealing for $30 \mathrm{~s}$, plus extension at $72^{\circ} \mathrm{C}$ for $30 \mathrm{~s}$, with final extension at $72^{\circ} \mathrm{C}$ for $8 \mathrm{~min}$. The $20 \mu \mathrm{l}$ of PCR product was mixed with $5 \mu \mathrm{l}$ loading buffer, denatured at $98^{\circ} \mathrm{C}$ for $10 \mathrm{~min}$ and then quickly placed into ice for $5 \mathrm{~min}$. $10 \mu \mathrm{l}$ of mixture was applied into (poly acrylamide: bisacrylamide 49:1) electrophoresed in 1X TBE buffer for $8-12 \mathrm{~h}$ at 140 to 160 voltage. The gel was stained with sliver according to standard protocol.

\section{Statistical analysis}

Allele frequency of the genetic data obtained by PCR-RFLP and PCR-SSCP was determined using Cerit et al. (2004) formula. Agreement of the genotype frequencies with the Hardy-Weinberg equilibrium expectations was tested using a chi square goodnessof-fit test using Chi-Square calculator V 1.51. The following model was fitted for association of each genotype with body weight and adipose tissue $\mathrm{Yij}=\mu+\mathrm{Mi}+$ eij where $\mathrm{Yij}$ is phenotypic value of (body weight or fat weight), $\mu$ is population mean, Mi is the fixed effect of the ith genotype and eij is random error effect of each observation, it was determined by ANOVA using general linear model GLM, all analysis was performed by SAS 9.0 software.

\section{RESULTS}

\section{PCR-RFLP and PCR-SSCP analysis}

In this study allele frequencies were performed by PCRRFLP and PCR-SSCP (Figure 1) and determined by direct gene counting for each locus in each chicken population. In Anka population allele frequency was significantly different $(P<0.01)$ at VLDL17 locus. However, in Rugao the gene frequency differed significantly $(P<0.01)$ at VLDL9 and VLDL 17 loci Table 2.

\section{Association of polymorphism in apoVLDL-II gene with body and fat weight}

Polymorphisms at VLDL9 and VLDL17 loci were significantly $(P<0.05)$ associated with body weight in Rugao population; it was high in the homozygous geno- 


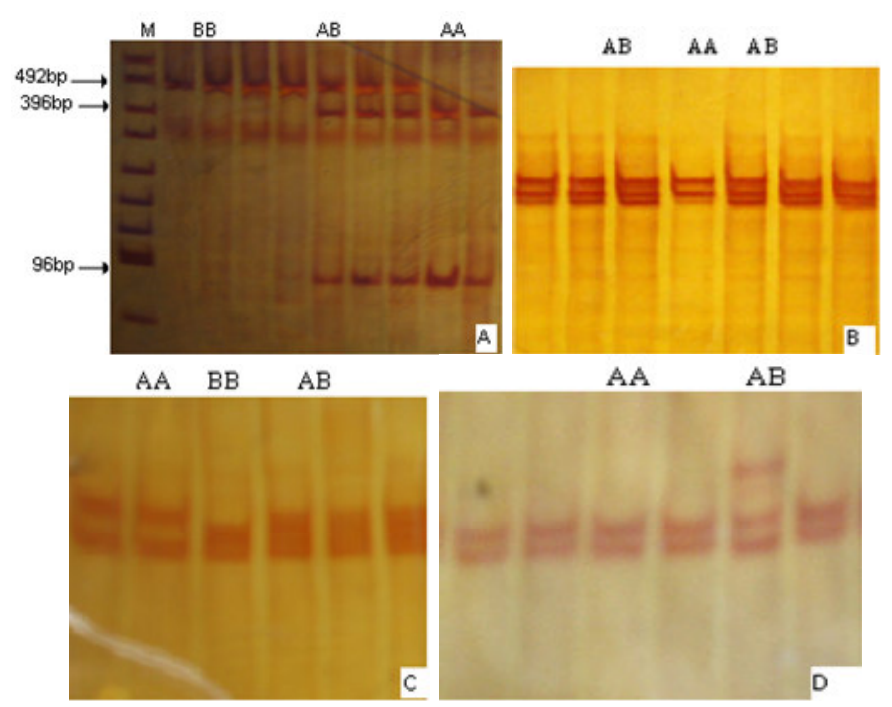

Figure 1. Polymorphisms of avian apoVLDL-II gene in genetically fat and lean chickens. A. PCR-RFLP analysis of VLDL6 locus; B. PCR-SSCP analysis of VLDL9 locus; C. PCR-SSCP analysis of VLDL10 locus; and D. PCR-SSCP analysis of VLDL17 locus). $M$ is pUC19DNA/Mspl (Hpall) marker.

Table 2. Allele frequencies of apoVLDL-II gene in chicken populations.

\begin{tabular}{|l|c|c|c|c|c|c|}
\hline & \multicolumn{7}{|c|}{ Allele frequencies } \\
\cline { 2 - 7 } Populations & \multicolumn{3}{|c|}{ Anka } & \multicolumn{3}{c|}{ Rugao } \\
\cline { 2 - 7 } & $\mathbf{G}$ & $\mathbf{A}$ & $\mathbf{X}^{\mathbf{2}}$ & $\mathbf{A}$ & $\mathbf{C}$ & $\mathbf{X}^{\mathbf{2}}$ \\
\hline VLDL6 & 0.932 & 0.068 & 0.06 & 0.983 & 0.017 & 0.00 \\
VLDL9 & 0.653 & 0.348 & 3.59 & 0.525 & 0.475 & $29.76^{* *}$ \\
VLDL10 & 0.805 & 0.195 & 0.02 & 0.593 & 0.407 & 3.86 \\
VLDL17 & 0.542 & 0.458 & $12.66^{\star *}$ & 0.712 & 0.288 & $37.05^{* *}$ \\
\hline
\end{tabular}

${ }^{* *}$ Chi-square $\left(X^{2}\right)$ value was significant at $(P<0.01)$.

type compared with the heterozygous. In addition, polymorphism in VLDL17 locus was associated significantly $(\mathrm{P}<0.05)$ with abdominal fat weight in Rugao breed. It was observed significantly high in homozygous genotype (Table 3). On the other hand, heterozygous genotype in VLDL6 locus observed significantly $(P<0.05)$ higher body weight and fat weight, whereas, in VLDL9 locus body weight and fat weight were significantly $(P<0.05)$ higher in homozygous genotype (Table 4$)$. In locus VLDL10 body and fat weight were significantly $(\mathrm{P}<0.05)$ different between apoVLDL-II genotypes.

\section{DISCUSSIONS}

A candidate gene research was a powerful method to investigate QTL that is responsible for genetic variation in the traits of interest in animals breeding (Rothschild and Soller, 1997). In this study the polymorphism of apoVLDL-II gene was detected by PCR-RFLP and PCR-
SSCP techniques, most of polymorphisms detected were located in non-coding region of the gene, and in exon4.The apo-VLDL-II is a yolk protein, is inducible by estrogen Lin et al. (1986), absent from plasma of immature hens, and inhibits lipoprotein lipase activity (Nimpt et al., 1988). Thus, estrogen may reduce lipid deposition in fat cells of mature hens. The apoVLDL-II gene contains sequences within its first intron that increase transcription (Berkowitz and Evans, 1992). The variation in allele frequencies between populations will reflect the distribution of genetic diversity within and amongst populations. The primary objective is to maximize the conservation of the genetic diversity available for potential future use. In this study we used chi-squared goodness of fit test to detect the allele variation. This statistical method quantifying the extent to which the observed and expected proportions of genotype counts for a specific DNA locus in a population, agree or disagree. The variations in allele frequencies in our study may be as a result of different breeding criteria for Chin- 
Table 3. Effect of breed and ApoVLDL-II gene polymorphisms on body weight and fat weight.

\begin{tabular}{|c|c|c|c|c|c|}
\hline Loci & Genotype & $\mathbf{N}$ & Body weight & Fat weight & Fat weight (\%) \\
\hline \multicolumn{6}{|l|}{ VLDL6 } \\
\hline \multirow[t]{2}{*}{ Anka } & AA & 51 & $3384.57 \pm 69.87$ & $55.84 \pm 1.39$ & $1.67 \pm 0.06$ \\
\hline & $A B$ & 8 & $3474.00 \pm 176.42$ & $56.69 \pm 3.52$ & $1.67 \pm 0.14$ \\
\hline \multirow[t]{2}{*}{ Rugao } & AA & 57 & $1121.00 \pm 23.14$ & $16.82 \pm 0.40$ & $1.52 \pm 0.03$ \\
\hline & $A B$ & 2 & $1029.50 \pm 123.55$ & $15.00 \pm 2.15$ & $1.46 \pm 0.15$ \\
\hline \multicolumn{6}{|l|}{ VLDL9 } \\
\hline \multirow[t]{2}{*}{ Anka } & $\mathrm{AA}$ & 18 & $3421.11 \pm 117.78$ & $57.36 \pm 2.34$ & $1.68 \pm 0.09$ \\
\hline & $A B$ & 41 & $3385.98 \pm 78.04$ & $55.34 \pm 1.55$ & $1.66 \pm 0.06$ \\
\hline \multirow[t]{2}{*}{ Rugao } & AA & 3 & $1335.00 \pm 96.96 a$ & $18.73 \pm 1.74$ & $1.40 \pm 0.12$ \\
\hline & $A B$ & 56 & $1106.27 \pm 22.44 b$ & $16.65 \pm 0.40$ & $1.53 \pm 0.03$ \\
\hline \multicolumn{6}{|l|}{ VLDL10 } \\
\hline \multirow[t]{3}{*}{ Anka } & $\mathrm{AA}$ & 38 & $3428.47 \pm 81.51$ & $57.29 \pm 1.59$ & $1.70 \pm 0.06$ \\
\hline & $A B$ & 19 & $3334.89 \pm 115.27$ & $54.15 \pm 2.25$ & $1.63 \pm 0.09$ \\
\hline & BB & 2 & $3380.00 \pm 355.28$ & $47.50 \pm 6.93$ & $1.40 \pm 0.28$ \\
\hline \multirow[t]{3}{*}{ Rugao } & AA & 16 & $1132.94 \pm 44.21$ & $16.84 \pm 0.77$ & $1.55 \pm 0.05$ \\
\hline & $A B$ & 38 & $1113.50 \pm 28.69$ & $16.71 \pm 0.50$ & $1.50 \pm 0.03$ \\
\hline & BB & 5 & $1103.20 \pm 79.08$ & $16.90 \pm 1.38$ & $1.55 \pm 0.09$ \\
\hline \multicolumn{6}{|l|}{ VLDL17 } \\
\hline \multirow[t]{2}{*}{ Anka } & AA & 5 & $3402.00 \pm 223.59$ & $63.54 \pm 4.33$ & $1.89 \pm 0.17$ \\
\hline & $A B$ & 54 & $3396.20 \pm 68.04$ & $55.25 \pm 1.32$ & $1.65 \pm 0.05$ \\
\hline \multirow[t]{2}{*}{ Rugao } & AA & 4 & $1319.50 \pm 83.29 a$ & $19.93 \pm .1 .46 a$ & $1.51 \pm 0.11$ \\
\hline & $A B$ & 55 & $1103.24 \pm 22.46 \mathrm{~b}$ & $16.53 \pm 0.39 b$ & $1.52 \pm 0.03$ \\
\hline
\end{tabular}

Means in a column that are followed by the different letter are significant at $(P<0.05)$.

Table 4. Effect of apoVLDL-II polymorphisms on body weight and fat weight.

\begin{tabular}{|l|c|c|c|c|c|}
\hline Loci & Genotype & N & Body weight & Fat weight & Fat weight (\%) \\
\hline VLDL6 & AA & 108 & $2189.91 \pm 114.21 \mathrm{a}$ & $35.25 \pm 1.99 \mathrm{a}$ & $1.71 \pm 0.03$ \\
& $\mathrm{AB}$ & 10 & $2985.10 \pm 375.33 \mathrm{~b}$ & $48.36 \pm 6.56 \mathrm{~b}$ & $1.67 \pm 0.10$ \\
\hline VLDL9 & $\mathrm{AA}$ & 21 & $3123.10 \pm 248.18 \mathrm{a}$ & $51.84 \pm 4.32 \mathrm{a}$ & $1.75 \pm 0.07$ \\
& $\mathrm{AB}$ & 97 & $2069.86 \pm 115.48 \mathrm{~b}$ & $33.00 \pm 2.01 \mathrm{~b}$ & $1.70 \pm 0.03$ \\
\hline VLDL10 & $\mathrm{AA}$ & 54 & $2748.32 \pm 152.87 \mathrm{a}$ & $45.31 \pm 2.65 \mathrm{a}$ & $1.76 \pm 0.04$ \\
\hline & $\mathrm{AB}$ & 57 & $1853.97 \pm 148.79 \mathrm{~b}$ & $29.19 \pm 2.57 \mathrm{~b}$ & $1.67 \pm 0.04$ \\
& $\mathrm{BB}$ & 7 & $1753.71 \pm 424.59 \mathrm{bc}$ & $25.64 \pm 7.35 \mathrm{bc}$ & $1.64 \pm 0.12$ \\
\hline \multicolumn{7}{|c|}{} \\
\hline \multicolumn{7}{|c|}{} \\
\hline
\end{tabular}

Means in a column that are followed by the different letter are significant at $(P<0.05)$

ese chicken such as meat quality, growth rate and or improved egg performance Zhang et al. (2002), it may also be due to reproductive isolation (Chenyambuga et al., 2004).

Polymorphism of apoVLDL-II gene at VLDL9 and VLDL17 loci were significantly associated with body weight and abdominal fat weight in genetically lean chicken. It is known that VLDL is the major transporter of triglycerides, and attempts to reduce excessive fatness in poultry have involved the control of VLDL metabolism. Therefore, lean and fat chicken lines have been divergently selected for adipose tissue weight (Leclercq 
et al., 1980) and for VLDL plasma concentration (Whitehead and Griffin, 1984). The combine analysis of fat and lean chicken shows apoVLDL-II gene was significantly $(P<0.05)$ associated with body weight and fat weight at VLDL6, VLDL9 and VLDL10 loci. Previous studies carried in obese functionally castrated hens, observed that when plasma level of apo-VLDL-II was low, plasma LPL activity was elevated, because obese functionally castrated hen had lower ovarian weight and plasma apo-VLDL-II and higher post heparin plasma LPL activity than obese laying hen (Jaccoby et al., 1996). Plasma level of apo-VLDL-II was negatively correlated with postheparin plasma LPL activity. Zollitsch et al. (1997) reported that the fatty acid pattern of the abdominal fat was significantly influenced by the dietary fatty acid. Studies performed in lean and fat line by Leclercq et al. (1980) indicated that the difference in adiposity between lines was not the result of a difference in food consumption or in metabolic utilization of energy. Stearoyl-CoA desaturase activity and plasma VLDL concentration were found to be higher in the fat line (Legrand and Hermier, 1992), suggesting a higher lipogenesis rate in this line. Body Selection for high VLDL has increase the proportion of circulating VLDL- triglyceride taken up by the abdominal fat pad by over 2 fold, but there was no difference between high and low VLDL lines in the proportion of VLDL triglyceride taken up by tissues and oxidized to 14C -carbon dioxide (Griffin et al., 1991).

\section{REFERENCES}

Berkowitz EA, Evans MI (1992). Functional analysis of regulatory regions upstream and in the first intron of the estrogen-responsive chicken very low density apolipoprotein II gene. J. Biol. Chem. 267(10): 7134-7138.

Cerit H, Altinel A, Elmaz O, Avanus K (2004). Polymorphism evaluation of various genomic loci in the kivircik sheep breed of Turkey. Turk. J. Vet. Anim. Sci. 28: 415-425.

Chenyambuga SW, Hanotte O, Hirbo J, Watts PC, Kemp SJ, Kifaro GC, Gwakisa PS, Peterson PH, Rege JEO (2004). Genetic characterization of indigenous goats of Sub-saharan Africa using microsatellite DNA markers. Asian-Aust. J. Anim. Sci. 17(4): 445452.

Griffin HD, Windsor D, Whitehead CC (1991). Changes in lipoprotein metabolism and body composition in chickens in response to divergent selection for plasma very low density lipoprotein concentration. Br. Poult. Sci. 32(1): 195-201.

Hache RJ, Wiskocil R, Vasa M, Roy RN, Lau PC, Deeley RG (1983). The 5 ' noncoding and flanking regions of the avian very low density apolipoprotein II and serum albumin genes. Homologies with the egg white protein genes. J. Biol. Chem. 258(7): 4556-64

Jaccoby RF, Marshall DJ, Newton MA, Novakovic K, Tutsch K, Cole CE, Lubet RA, Kelloff, GJ, Verma A, Moser AR, Dove WF (1996). Chemoprevention of spontaneous intestinal adenomas in the $A p c^{\mathrm{Min}}$ mouse model by the nonsteroidal anti-inflammatory drug piroxicam. Cancer Res. 56: 710-714.
Leclercq B, Blum JC, Boyer JP (1980). Selecting broilers for low or high abdominal fat: initial observations. Br. Poult. Sci. 21: 107-113.

Legrand P, Hermier D (1992). Hepatic $\mathbf{A} 9$ desaturation and plasma VLDL level in genetically lean and fat chickens. Int. J. Obes. 16: 289294.

Li H, Deeb N, Zhou H, Ashwel CM, Lamont SJ (2005). Chicken quantitative trait loci for growth and body composition associated with the very low density Apolipoprotein-II gene. Poult. Sci. 84: 697703.

Lin CT, Palmer W, Wu JY, Chan L (1986). Estrogen induction of very low density apolipoprotein II synthesis, a major avian liver yolk protein, involves the recruitment of hepatocytes. Endocrinology 118(2): 538-544.

Musa HH, Chen GH, Cheng JH, Li BC, Mekki DM (2006). Study on carcass characteristics of chicken breeds raised under the intensive condition. Int. J. Poult. Sci. 5(6): 530-533.

Nimpf J, George R, Schneider WJ (1988). Apolipoprotein specificity of the chicken oocyte receptor for low and very low density lipoproteins: lack of recognition of apolipoprotein VLDL-II. J Lipid Res. 29(5): 657-667.

Orita M, Suzuki Y, Sekiya T, Hayashi K (1989). Rapid and sensitive detection of point mutations and DNA polymorphisms using the polymerase chain reaction. Genomics 5: 874-879.

Peebles ED, Burnham MR, Walzem RL, Branton RL, Gerard PD (2004). Effects of fasting on serum lipids and lipoprotein profiles in the egglaying hen (Gallus domesticus). Comp. Biochem. Physiol. Part A. 138: 305-311.

Rothschild MF, Soller M (1997). Candidate gene analysis to detect genes controlling traits of economic importance in domestic livestock. Probe Newsletter for Agriculture Genomic 8(2): 13-20.

Sambrook J, Fristch EF, Manistais T (1989). Molecular cloning: A laboratory manual: Vol.3. Cold Spring Harbor Laboratory Press. Cold Spring Harbor. USA.

Schneider WJ, Carrol R, Severson DL, Nimpf J (1990). Apolipoprotein VLDL-II inhibits lipolysis of triglyceride-rich lipoproteins in the laying hen. J. Lipid Res. 31(3): 507-513.

Walzem RL, Davis PA, Hansen RJ (1994). Overfeeding increases very low density lipoprotein diameter and causes the appearance of a unique lipoprotein particle in association with failed yolk deposition. J. Lipid Res. 35: 1354-1366.

Whitehead CC, Griffin HD (1984). Development of divergent lines of lean and fat broilers using plasma very low density lipoprotein concentration as selection criterion: the first three generations. $\mathrm{Br}$. Poult. Sci. 25: 573-582.

Zhang X, Leung FC, Chan DKO, Yang G, Wu C (2002). Genetic diversity of Chinese native chicken breeds based on protein polymorphism, randomly amplified polymorphic DNA and microsatellite polymorphism. Poult. Sci. 81: 1463-1472.

Zollitsch W, Knaus W, Aichinger F, Lettner F (1997). Effects of different dietary fat sources on performance and carcass characteristics of broilers. Anim. Feed Sci. Tech. 66: 63-73. 